\title{
Assessing Rainwater Harvesting Potential in Urban Areas: A Building Information Modelling (BIM) Approach
}

\author{
Ahsen Maqsoom ${ }^{1} \mathbb{D}$, Bilal Aslam ${ }^{2} \mathbb{D}$, Sharjeel Ismail ${ }^{1}$, Muhammad Jamaluddin Thaheem ${ }^{3} \mathbb{D}$, Fahim Ullah ${ }^{4}(\mathbb{D}$, \\ Hafiz Zahoor ${ }^{5}$ (D), Muhammad Ali Musarat ${ }^{6, *(D)}$ and Nikolai Ivanovich Vatin ${ }^{7}$ (D)
}

Citation: Maqsoom, A.; Aslam, B.; Ismail, S.; Thaheem, M.J.; Ullah, F.; Zahoor, H.; Musarat, M.A.; Vatin, N.I. Assessing Rainwater Harvesting Potential in Urban Areas: A Building Information Modelling (BIM) Approach. Sustainability 2021, 13, 12583. https://doi.org/10.3390/ su132212583

Academic Editors: Grigorios

L. Kyriakopoulos and

Mohammad Valipour

Received: 17 September 2021

Accepted: 11 November 2021

Published: 15 November 2021

Publisher's Note: MDPI stays neutral with regard to jurisdictional claims in published maps and institutional affiliations.

Copyright: (c) 2021 by the authors. Licensee MDPI, Basel, Switzerland. This article is an open access article distributed under the terms and conditions of the Creative Commons Attribution (CC BY) license (https:// creativecommons.org/licenses/by/ $4.0 /)$.
1 Department of Civil Engineering, COMSATS University Islamabad Wah Campus, Wah Cantt 47040, Pakistan; ahsen.maqsoom@ciitwah.edu.pk (A.M.); sherjeel1996@hotmail.com (S.I.)

2 Department of Data Science, Riphah International University, Islamabad 45320, Pakistan; bilalaslam45@gmail.com

3 School of Architecture and Built Environment, Deakin University, Geelong, VIC 3220, Australia; jamal.thaheem@deakin.edu.au

4 School of Civil Engineering and Surveying, University of Southern Queensland, Springfield, QLD 4300, Australia; fahim.ullah@usq.edu.au

5 Department of Construction Engineering and Management, National University of Sciences and Technology, Risalpur Campus, KPK 24080, Pakistan; hafiz.zahoor@mce.nust.edu.pk

6 Department of Civil and Environmental Engineering, Universiti Teknologi PETRONAS, Bandar Seri Iskandar 32610, Malaysia

7 Peter the Great St. Petersburg Polytechnic University, 195251 St. Petersburg, Russia; vatin@mail.ru

* Correspondence: muhammad_19000316@utp.edu.my

\begin{abstract}
Water scarcity has become a major problem for many countries, resulting in declining water supply and creating a need to find alternative solutions. One potential solution is rainwater harvesting $(\mathrm{RwH})$, which allows rainwater to be stored for human needs. This study develops an $\mathrm{RwH}$ assessment system through building information modeling (BIM). For this purpose, a hydrological study of Cfa-type climate cities is conducted with the example of Islamabad, Pakistan. The monthly rainfall data of three sites were assessed to determine the volume of the accumulated rainwater and its potential to meet human needs. The average number of people living in a house is taken as the household number. Household number or of the number of employees working at a small enterprise, roofing material, and rooftop area are used as the key parameters for pertinent assessment in the BIM. The data simulated by BIM highlight the $\mathrm{RwH}$ potential using five people per house as the occupancy and a $90 \mathrm{~m}^{2}$ rooftop area for residential buildings or small enterprises as parameters. The results show that the selected sites can collect as much as $8,190 \mathrm{~L} / \mathrm{yr}$ of rainwater (48 L/person/day) to 103,300 L/yr of rainwater (56 L/person/day). This much water is enough to fulfill the daily demands of up to five people. Therefore, it is established that the study area has an $\mathrm{RwH}$ potential that is able to meet the expected demands. This study presents a baseline approach for $\mathrm{RwH}$ to address water scarcity issues for residential buildings and factories of the future.
\end{abstract}

Keywords: rainwater harvesting $(\mathrm{RwH})$; water demand; building information modeling (BIM); hydrological investigation; sustainable drainage systems (SuDs); residential buildings

\section{Introduction}

The global population is increasing exponentially, presenting many challenges and managerial issues such as water scarcity and pertinent water management. Water scarcity is a real problem that is caused by the rapid depletion of groundwater resources and population growth. Approximately $4430 \mathrm{~km}^{3}$ of freshwater is utilized globally, from which $70 \%$ is used in agriculture, $25 \%$ is used in industry, and $5 \%$ is used in households [1]. Furthermore, the world population will likely increase from 7 billion to 10 billion by 2050 [2], exacerbating the water demand and supply situation. Accordingly, it is predicted that around $20 \%$ of the global population will live under a severe water shortage due to a $2{ }^{\circ} \mathrm{C}$ 
increase in the global temperature [3]. Increasing the global demand for natural resources has resulted in the creation of the Factories of the Future approach [4]. Furthermore, recent years have shown that groundwater use has increased, leading to its depletion and contamination [5]. This increase presents serious water management problems, outbreaks of waterborne diseases, and water scarcity issues to city planners, health, and governance teams. Hence, to prevent such outbreaks and to obtain health benefits, the supply of domestic-purpose water needs to be sustained [6,7].

$\mathrm{RwH}$ is a new concept in green infrastructure initiatives that is gaining importance in dealing with the global water issues caused by [8]. Rainwater harvesting technologies and strategies (RwHTS) have many benefits. These include reduced environmental and health effects, less rainwater runoff, and economic viability [9]. A study of rainwater management reports that rainwater runoff can be controlled using sustainable design structures [10]. Additionally, it also facilitates the soil to absorb moisture. Thus, it can assist in the recharging of the local groundwater aquifer [11].

Thus, RwHTS can be leveraged to develop a self-sufficient and sustainable built environment. However, built environment projects are generally criticized for their underperformance in quality, product delivery, and customer satisfaction due to manual, conventional planning, designing, estimating, and managing that are needed [12-18]. BIM was introduced as a panacea for the issues faced by the architecture, engineering, and construction (AEC) industry. BIM can support achieving sustainable building design (reduced costs) [19,20], daylighting analysis, water harvesting, energy-saving designs [21,22], the use of sustainable materials [23], and lower lifecycle costs [24]. Siddiqui, Pearce [25] presented detailed implications of BIM tools in achieving sustainability, where the authors discussed the use of BIM for the simulation and analysis of sustainable structures. In the same spirit, $\mathrm{RwH}$ structures can be built using BIM [23]. The further development of BIM uses integrated BIM technologies [26]. Langar and Pearce [27] conducted a survey-based study of BIM and RwH to identify BIM implementation in the United States and the type of RwH structures constructed by the design firms.

Groundwater is used extensively in Pakistan's domestic, industry, and agriculture sectors due to the rapidly [27] increasing population and their associated water needs [28]. Due to the increased population and a reduced surface water supply, there is great stress on groundwater aquifers [29]. It was reported that the annual global groundwater extraction in 2010 was $982 \mathrm{~km}^{3}$. Moreover, it is predicted that by 2030, Pakistan will become the country with less renewable water resources and water resources that are below the threshold value of $1500 \mathrm{~m}^{3}$ [30]. Therefore, an artificial recharge process needs to be adopted and implemented in the country on an emergency basis if the emergent water scarcity issues are to be managed in order to stop the groundwater table from depleting.

Recharging is the process of water infiltration into the soil and then into the saturated zone [31]. Bhutta and Alam [32] recommended that artificial groundwater recharge be promoted in the areas where these structures are possible to build and are economical. One of the best possible alternatives to recharge the groundwater table is the $\mathrm{RwH}$ structures and strategies. Moreover, being contained and reused after purification, the wastewater can help reduce water scarcity [33]. However, research on rainwater management shows that if rainwater is stored in either porous or with a filter discharge valve, then the water will eventually infiltrate into the phreatic zone, recharging the aquifer [34].

RwHS can be difficult to develop when analyzing the weather, tank size, site, and utilization of conserved water [35]. Additionally, they cause the projects significant frontend load in terms of resources and demand interdisciplinary expertise [36]. Thus, $\mathrm{RwH}$ projects are difficult to implement, but they mitigate the developmental effects when they are properly executed. Therefore, it is important to leverage technological innovation to improve the design and sustainability of RwHS. BIM can achieve a sustainable design and better collaboration with stakeholders to obtain a successful $\mathrm{RwH}$ project. Enhanced virtual designs of the systems or materials and their geometry facilitate the development 
of a structure's cost-effectiveness, site safety, and sustainability [37]. Using green building technology, BIM leads to better and more efficient facilities $[25,38]$.

Research suggests that BIM should be used as a product and a process [39]. BIM contributes to the planning and the design process, which is often iterative between the individuals who are involved in the project [40]. Moreover, it allows multidimensional data that can be superimposed onto the model during the design process. Accordingly, the sustainability measures can be incorporated into the model [41,42]. BIM also aids in the graphical and non-graphical visualization of a structure [43] and provides a realistic database that helps better cooperation between the key project stakeholders [44]. Overall, BIM has a positive risk tradeoff in which its benefits outweigh its implementation challenges [45]. However, despite the advantages of BIM, it has its fair share of criticism and limitations. For example, researchers consider integrating its software with other subjects as its limiting factor $[46,47]$.

Based on the above motivation, the application of $\mathrm{RwH}$ is linked to the application of BIM in this research. BIM helps to perform complex simulations and to reach better and improved decisions. Therefore, new tools and techniques that help execute $\mathrm{RwH}$ structures, such as BIM, should be leveraged. Of these tools, InfraWorks evolved as an innovation by Autodesk, which helps to conceptualize, contextualize, optimize, and visualize projects [48]. The literature suggests that $\mathrm{RwH}$ is a viable solution in areas with higher precipitation. As a process, BIM can be highly effective in analyzing the $\mathrm{RwH}$ potential for such residential areas. Therefore, the current study humbly contributes to the body of knowledge by applying BIM for assessing the potential of $\mathrm{RwH}$ in residential buildings. The household size was determined from the publication, local area knowledge, and investigation, indicating the number of people living in a typical house and their water demands in the case study area. Although the analysis is regional (Islamabad, Pakistan), the outcome will benefit other regions with the same topographical features. The published studies are conventional; the proposed structures are not cost-effective, and there is no proper estimation of the storage structures based on the rainfall trends. These are useful for laying the foundation of rainwater harvesting schemes; however, new studies focused on cost-effectiveness and detailed conceptual designs of RwHs can contribute a lot towards sustainable water consumption and the saving of water.

\section{Materials and Methods}

This research is based on the latest experiences of evaluating RwH potential in the study area. For optimal results, the catchment surface for the RwH structure should be 200-300 $\mathrm{m}^{2}$. In these conditions, water can be saved by as much as $85 \%$. On the other hand, if the catchment surface is smaller than required, the RwH structure will not produce desirable results because of the requirements for larger tank sizes [49].

Rainfall patterns were studied to establish the seasonal rainfall trend and rainfall pattern across each month of a year to define the water availability so that the consistency of rainwater as a substitute water supply source can be justified. Rainfall data were analyzed to meet the research objectives. The house scale, size, and materials for the roof and storage tank capacity were defined using statistical methods. The study area for this research is Islamabad, the capital of Pakistan. However, any city in the world can be taken into account for this research. The population and associated water demand of this city are increasing rapidly [50]. However, the water supply is limited due to a decrease in rainfall and limited water resources. Hence, to provide sustainable water availability, it is important to utilize the $\mathrm{RwH}$ potential. For the residential areas, rainwater can be stored in buildings and recycled for domestic purposes. It is essential to mention that the current research is executed on existing designs and technologies that generally apply to the study area.

The climate of Islamabad is a Cfa (humid subtropical climate), as per the Köppen climate classification. The following approaches, assumptions, and data sources have been adopted and utilized in this study: 
- Rainfall data were only available for these three sites (Table 1) and were taken from the Pakistan Meteorological Department (PMD) (https:/ / www.pmd.gov.pk accessed on 6 June 2021).

- $\quad$ Proposed sites were visited, common structures of the surrounding building were considered, and the roof area was calculated.

- A concrete surface, which is more viable and smoother regarding water flow with a slope of $5^{\circ}$, was developed and used.

- $\quad$ The roofing area (RA) was calculated according to the equation suggested by [51].

- The runoff coefficient of the rainwater was taken from [49].

- $\quad$ RA of $90 \mathrm{~m}^{2}$, a coefficient of 0.8 , and the monthly average rainfall for the last four years were used to find the monthly $\mathrm{RwH}$ potential in liters in the case study area.

- The cumulative RwH potential was derived from each month's RwH potential.

- The average difference between the demand line and the accumulated rainfall provides the tank storage capacity for the storage of all of the accumulated rainwater.

The methodology of this research is shown in Figure 1 and is subsequently explained.

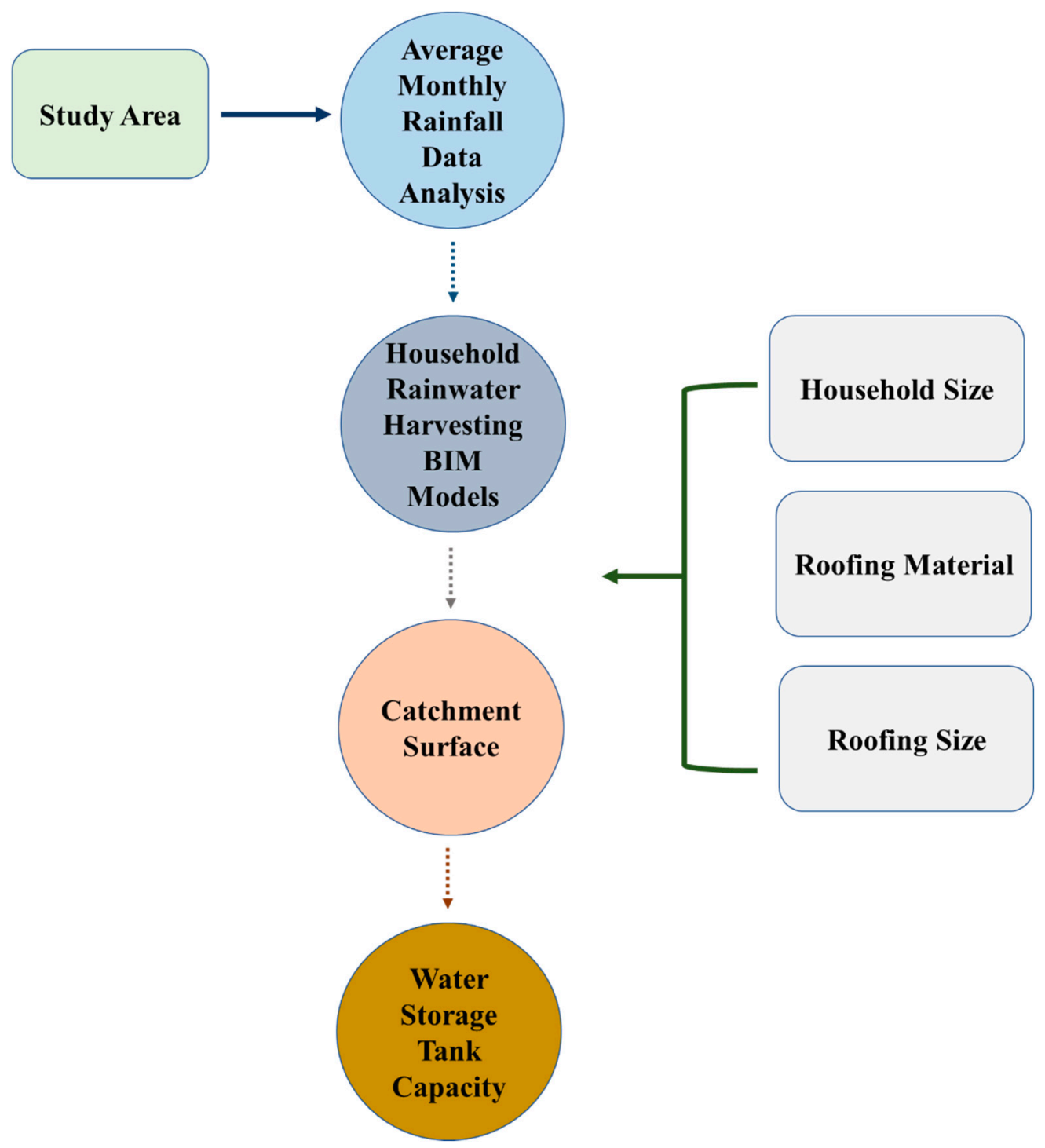

Figure 1. Research methodology. 
Table 1. Details of study sites in Islamabad.

\begin{tabular}{ccc}
\hline Site No. & Site Name & Location (Latitude, Longitude) \\
\hline 1 & Zero Point & $33^{\circ} 41^{\prime} 38^{\prime \prime}, 73^{\circ} 03^{\prime} 55^{\prime \prime}$ \\
2 & Airport & $33^{\circ} 33^{\prime} 41^{\prime \prime}, 72^{\circ} 51^{\prime} 25^{\prime \prime}$ \\
3 & Rawat & $33^{\circ} 31^{\prime} 26^{\prime \prime}, 73^{\circ} 10^{\prime} 17^{\prime \prime}$ \\
\hline
\end{tabular}

\subsection{Study Area}

The study area is Islamabad, the capital of Pakistan (Figure 2). It is an organized and maintained city that lies on the edge of the Pothohar Plateau and at the footsteps of the Margalla Hills, with an elevation of $507 \mathrm{~m}$ from sea level. The total area of Islamabad is $906.50 \mathrm{~km}^{2}$ [52]. The terrain of the city consists of plains and mountains. The city is located between $72^{\circ} 48^{\prime}$ and $73^{\circ} 22^{\prime}$ east longitude and $33^{\circ} 28^{\prime}$ and $33^{\circ} 48^{\prime}$ north latitude. Islamabad is a semi-arid city with an average annual rainfall of $95.2 \mathrm{~mm}$. Moreover, maximum rainfall occurs in July and August [6]. Islamabad has a humid subtropical climate with five seasons that include winter (November-February), spring (March and April), summer (May and June), monsoon (July and August), and autumn (September and October) [53]. The average high and low temperatures in winter are $16.6^{\circ} \mathrm{C}$ and $3.4^{\circ} \mathrm{C}$, respectively, and in summer, the average high and low temperatures are $34.2^{\circ} \mathrm{C}$ and $24.4^{\circ} \mathrm{C}$, respectively.

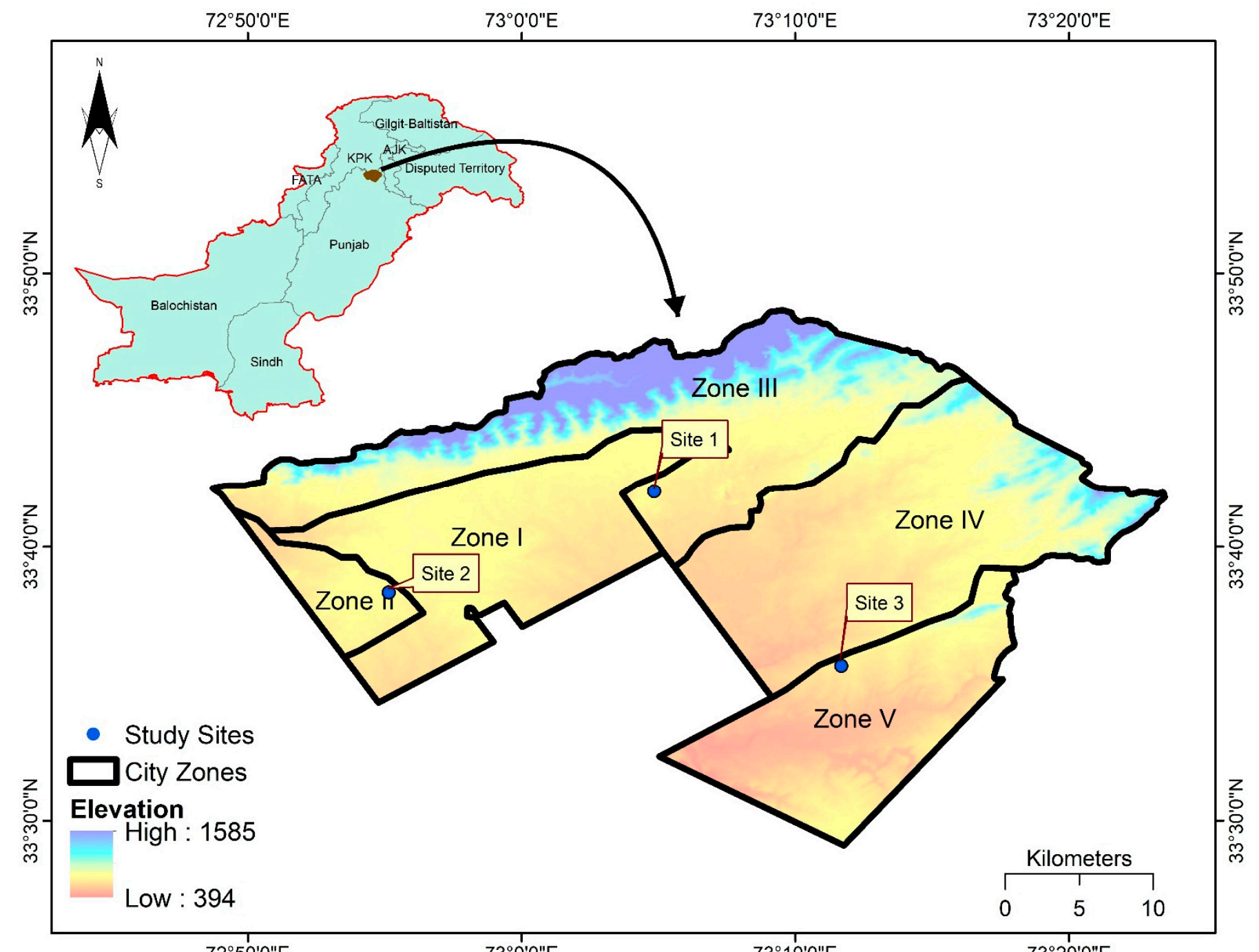

Figure 2. Location of the study area and the study sites. 
The population of Islamabad is around 2 million people, and most residents are immigrants from other parts of the country. The major reason behind this immigration is the city's status as the federal capital, meaning that it houses government machinery, universities, and several allied services. Such migration causes an increase in population, stressing the natural resources and adversely affecting the environment [54].

For the groundwater, around 180 tube wells pump water and supply it to different sectors of Islamabad. Municipal and private wells also fulfill the water demands of the population, leading to a rapid drop in groundwater levels. Islamabad is divided into five zones based on its development potentials and aims [52]. These include Zone I: designated for urban development and federal government institutions, Zone II: designated for urban development, Zone III: designated for rural development, Zone IV: designated for rural development, and Zone V: designated for rural development. Furthermore, Figure 2 shows the elevations of these five zones in Islamabad. From the legends, blue denotes the highest elevated areas, red shows the lowest elevation, and the bold line marks the borders of the zones. From these zones, three sites are selected to identify the RwH potential because of the limited data availability. The data were acquired from the PMD rain gauges that are installed in these zones. Hence, these sites were selected, and their rainfall data were incorporated. The selected three sites are considered due to their high population and because the buildings in these areas show a similar construction design. Hence, the same methodology can be applied to all three sites. Rainfall data from the last five years were considered, and the average value for each month was used in the associated assessments. The climate of these sites is almost the same, as they are in a close vicinity to each other. Details of these sites are given in Table 1 and are displayed in Figure 2 as Site 1, 2, and 3.

\subsection{Rainfall Data Acquisition and Details}

Daily rainfall data were acquired from the PMD website. The three sites were strategically selected since the PMD has installed rain gauges at these locations. This data helped to design the average rainfall for each month for Islamabad. First, the rainfall data from the last five years, i.e., January 2014 to December 2018, were used to derive the average rainfall of the study area. Then, the monthly average rainfall data were used to statistically analyze the data to identify which months receive the highest rainfall and which season faces severe scarcity. Once this relation is derived, water management strategies can be proposed since they provide details on when water should be stored for future use. Moreover, this relationship provides the details in calendar months.

\subsection{Modeling and Simulation of the Data}

BIM is a process that includes the collaboration of different software packages for better project output and data analysis, as shown in Figure 3a. In this study, the 2D model of the houses was built using AutoCAD ${ }^{\circledR}$. After this, the 2D models were converted into 3D models, and a roof slope was defined for the building. The model was further developed in Revit ${ }^{\circledR}$ and was subsequently imported into SketchUp ${ }^{\circledR}$ for the additional modeling of piping structures to collect rainwater. Finally, all of these models were imported in InfraWorks ${ }^{\circledR}$ Version 2019. After the 3D file of the model was imported, its configuration was completed, and the data file was assigned a specific domain. The configuration requires the data file to be assigned with a coordinate system, as shown in Figure 3b. The WGS-1984 coordinate system was selected for the current study, as shown in Figure 3b. After placing the model in its desired position, properties such as slope, elevation, height, etc., can be changed from the properties panel. The slope for the model was kept at $5^{\circ}$, as shown in Table 2. There were no issues regarding the development of the structures because the tools that were adopted were user-friendly. However, a powerful operating system and computer with high specifications must be used in order to process and run these tools. 


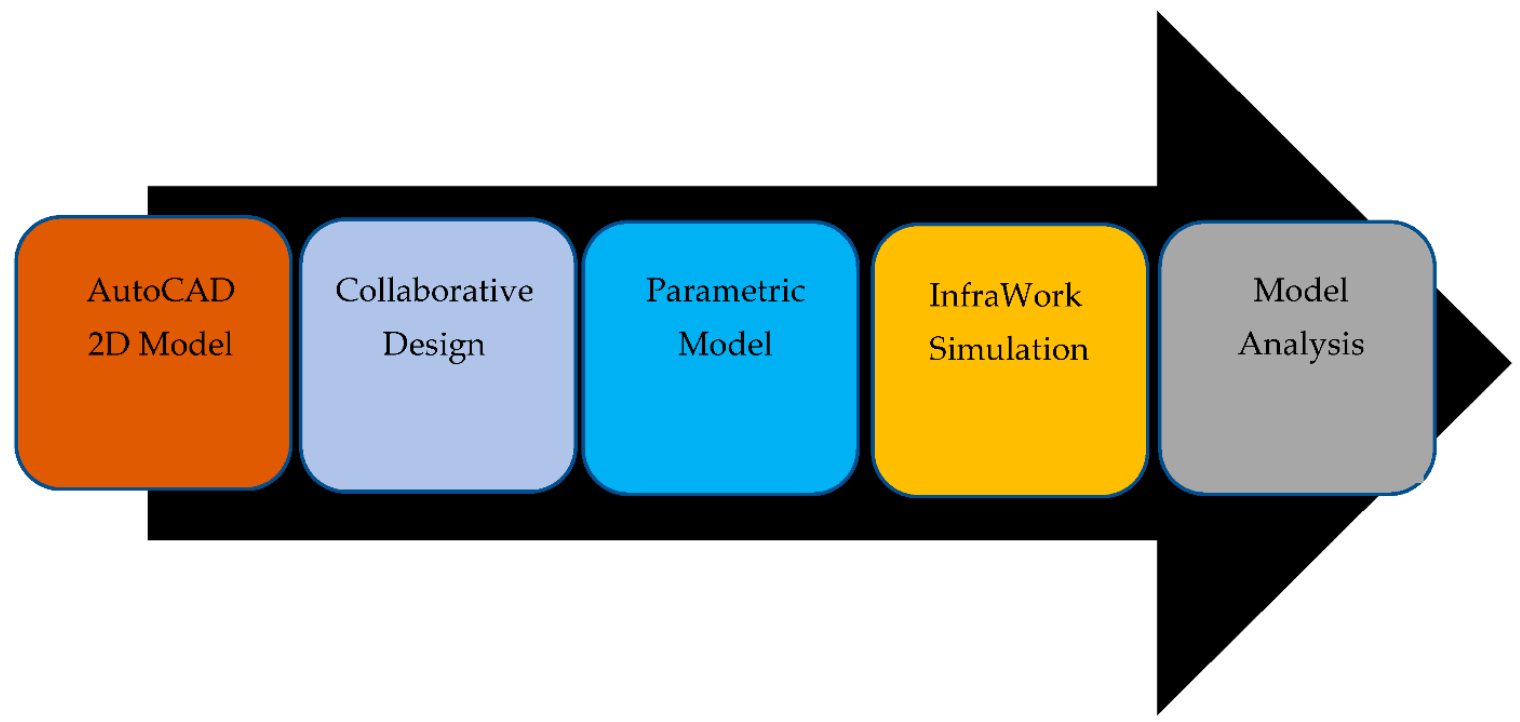

(a)

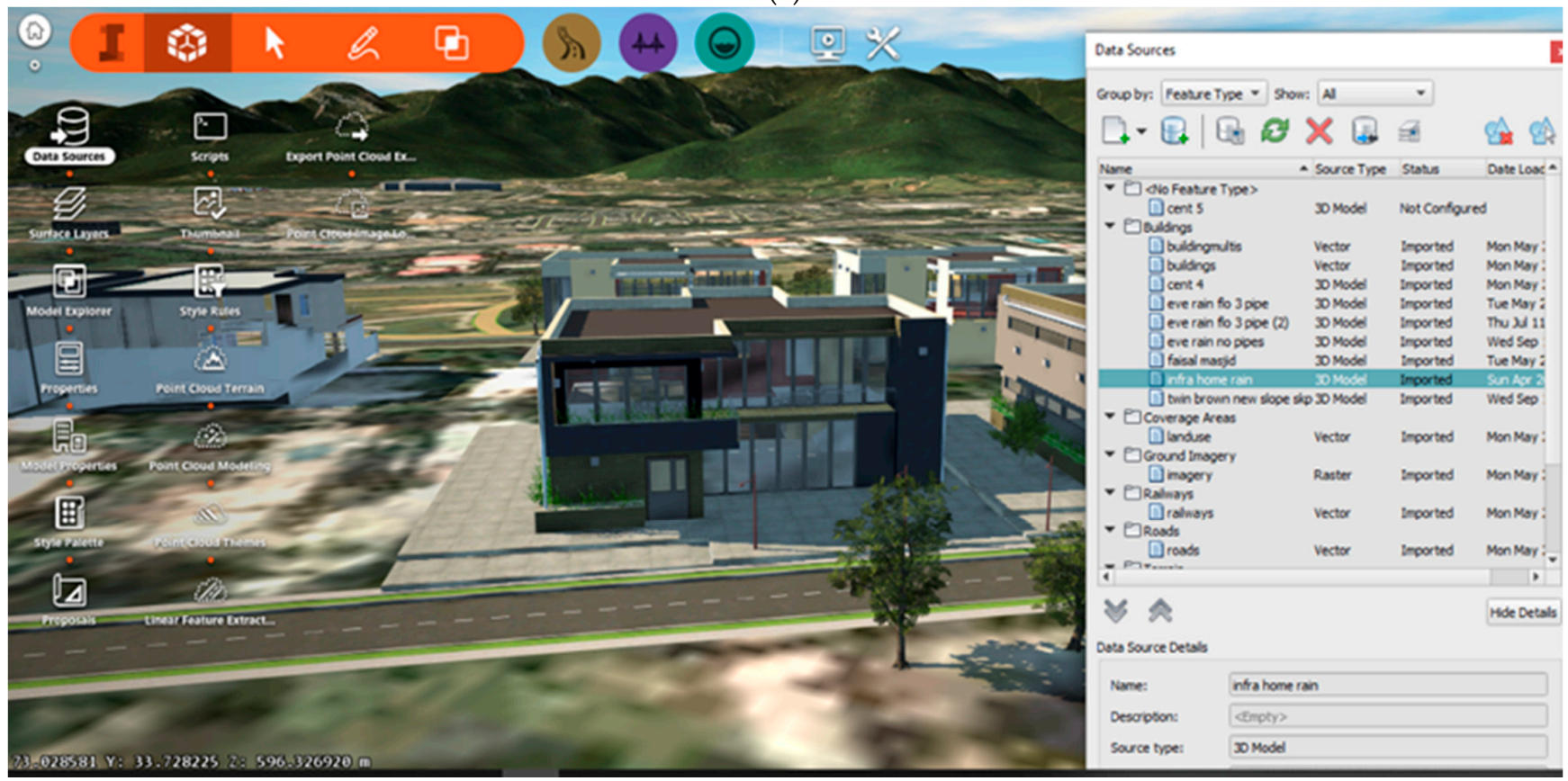

(b)

Figure 3. Figure caption (a) BIM process. (b) Data source visualization in InfraWorks.

Table 2. Model properties in InfraWorks ${ }^{\circledR}$.

\begin{tabular}{cc}
\hline Properties & Description \\
\hline Roof height & $3.0 \mathrm{~m}$ \\
Roof slope & $5.0^{\circ}$ \\
Roofing material & Concrete \\
Roofing size & $90 \mathrm{~m}^{2}$ \\
Building type & Double story residential house \\
\hline
\end{tabular}

Based on the local information and literature, typical residential buildings were designed at all of the selected sites in InfraWorks ${ }^{\circledR}$, as shown in Figure 4. First, the buildings were designed followed by the household numbers, which were statistically identified. Then, in terms of the building structure attributes, roofing material was added, 
and the associated roof area was calculated through statistical relation. Finally, the entire model was designed from pipeline development to storage plant and purification, as shown in Figures 4 and 5. Overall, the description of the RwH model in InfraWorks ${ }^{\circledR}$ is presented in Table 3.

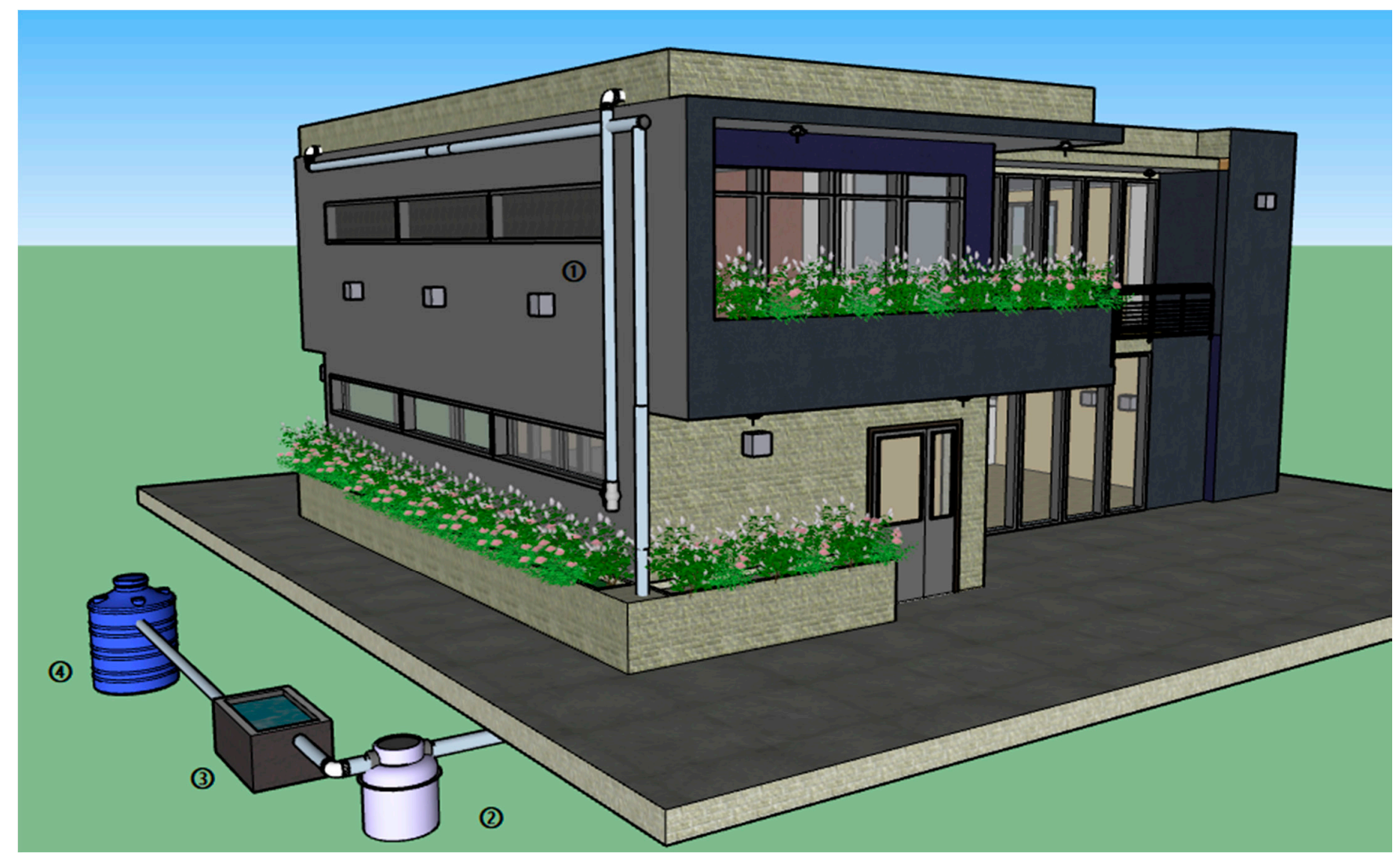

Figure 4. 3D model of the facility subject to the process of rainwater harvesting along with all the necessary components for its purification.

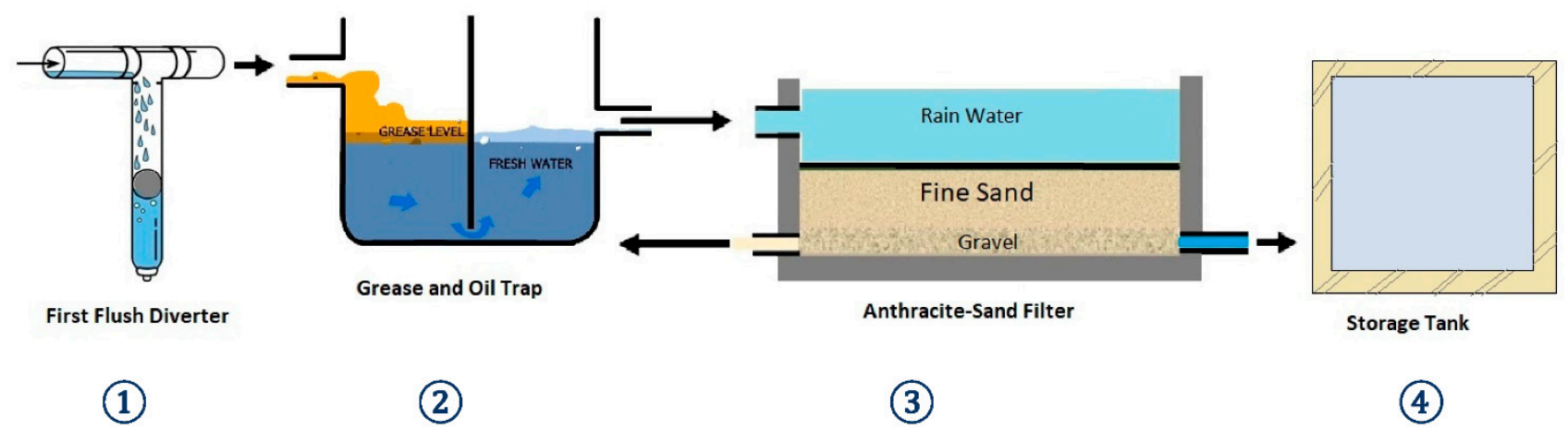

Figure 5. Schematic representation of the treatment for rainwater. 
Table 3. Description and functions of RwH model components.

\begin{tabular}{|c|c|c|c|c|}
\hline S.No. & Component & Description & Function & Specification \\
\hline 1. & $\begin{array}{l}\text { First flush } \\
\text { diverter }\end{array}$ & $\begin{array}{l}\text { It diverts the first few } \\
\text { liters of dirty rainwater } \\
\text { to another pipe from } \\
\text { where it can be flushed } \\
\text { out. }\end{array}$ & $\begin{array}{l}\text { It consists of an assembly of a pipe, a } \\
\text { ball, and a valve. When the rainwater } \\
\text { travels through the flush diverter pipe, } \\
\text { it forces a ball at the bottom to rise up } \\
\text { and finally seals off the pipe. This way, } \\
\text { some dirty water is stored in the pipe, } \\
\text { which is later flushed out by opening } \\
\text { the valve. }\end{array}$ & $\begin{array}{l}\text { Four first flush diverters are } \\
\text { used in this model, one for each } \\
\text { pipeline, collecting rainwater } \\
\text { from the roof. } \\
\text { This way, the first } 10 \mathrm{~L} \\
\text { accumulated from the rooftop } \\
\text { are flushed, and the remaining } \\
\text { water heads towards the } \\
\text { cleaning stage. }\end{array}$ \\
\hline 2. & $\begin{array}{l}\text { Grease and oil } \\
\text { trap }\end{array}$ & $\begin{array}{l}\text { It allows the separation } \\
\text { of grease and oil traces } \\
\text { in the water } \\
\text { accumulated from the } \\
\text { roof. }\end{array}$ & $\begin{array}{l}\text { It consists of a container with a gate } \\
\text { panel placed in the middle. The water } \\
\text { enters from one side of the container; } \\
\text { the solids settle at the bottom while the } \\
\text { oil and grease float at the top. The clear } \\
\text { water then enters the other side of the } \\
\text { container from under the gate panel and } \\
\text { exits. }\end{array}$ & $\begin{array}{l}\text { The dimensions of the container } \\
\text { are } 400 \times 400 \times 250 \mathrm{~mm} \text {, with } \\
\text { an overflow height of } 220 \mathrm{~mm} \text {. } \\
\text { The container has a capacity of } \\
35.3 \mathrm{~L} \text {. }\end{array}$ \\
\hline 3. & $\begin{array}{l}\text { Anthracite- } \\
\text { sand } \\
\text { filter }\end{array}$ & $\begin{array}{l}\text { It removes the smallest } \\
\text { impurities present in } \\
\text { the water by refining } \\
\text { through fine sand. }\end{array}$ & $\begin{array}{l}\text { It consists of a reservoir with a layer of } \\
\text { Schmutzdecke, a layer of fine sand, and } \\
\text { a layer of gravel. The water enters the } \\
\text { tank from above and passes through all } \\
\text { of these layers to be purified. This filter } \\
\text { also requires backwashing from time to } \\
\text { time (3-7 days) to prevent blockage of } \\
\text { pores. }\end{array}$ & $\begin{array}{l}\text { The top layer (Anthracite) has a } \\
\text { thickness of } 250 \mathrm{~mm} \text {, the bottom } \\
\text { layer, which consists of sand, has } \\
\text { a thickness of } 300 \mathrm{~mm} \text {, and the } \\
\text { support gravel layer has a } \\
\text { thickness of } 430 \mathrm{~mm} \text {. }\end{array}$ \\
\hline 4. & Storage tank & $\begin{array}{l}\text { It collects the purified } \\
\text { rainwater ready for } \\
\text { use. }\end{array}$ & $\begin{array}{l}\text { It is normally } 1520-2130 \mathrm{~mm} \text { high and is } \\
\text { made of PVC. A water tap may be } \\
\text { attached for direct access to water and a } \\
\text { drainage nozzle to convey water to the } \\
\text { main tank. }\end{array}$ & $\begin{array}{l}\text { A 3000-L capacity storage tank is } \\
\text { selected with a diameter of } 1625 \\
\mathrm{~mm} \text { and } 1828 \mathrm{~mm} \text { in height. }\end{array}$ \\
\hline
\end{tabular}

\subsubsection{Household Number}

It is imperative to calculate the household size for the $\mathrm{RwH}$ calculations from the mass curve analysis technique [55]. Household size indicates the total water demand and the storage capacity of a house to fulfill that demand. The majority of the population has a household size of four to six people in the study area. Therefore, the standard average of five people in each house is taken for storage capacity analysis. Hence, in InfraWorks simulation, all the houses on all three sites have a household size of five.

\subsubsection{Roofing Materials}

Almost $80 \%$ of the population lives in detached houses in Islamabad, while $20 \%$ live in flats and apartments. Most of the houses in Islamabad are constructed with cementconcreted rooftops, and a small percentage of houses have tiles as the roofing material. Such material is useful for $\mathrm{RwH}$ because runoff from concrete surface is very rapid, and water losses are minimal. Hence, in the InfraWorks simulation, all of the rooftops are made of cement concrete.

\subsubsection{Roofing Size}

As mentioned earlier, most of the population lives in houses (almost $80 \%$ ), while the rest live in Islamabad's flats. Therefore, it is very difficult to estimate the roof size for a flat, and there are hardly any data available for the roof area (RA) of flats. Nevertheless, it is understood that the roof size area for a house is larger than the roof size area of flats. Since no official data were available, local on-ground knowledge and experience were taken into 
account, and an area of $108 \mathrm{~m}^{2}$ was assumed for houses while considering the statistical standard for $3.75 \mathrm{~m}^{2}$ /person for flats means that for a five-person flat, approximately $18.75 \mathrm{~m}^{2}(3.75 \times 5)$ of RA per flat can be considered [51]. Hence, the weighted average for the roof area was calculated using Equation (1), where RA represents the roof area per house $\left(\mathrm{m}^{2}\right), H_{p}$ is the percentage of houses in the city, which was taken as $80 \%, H_{a}$ is the average roof area of the houses in the city, which was taken as $108 \mathrm{~m}^{2}$, and $F_{p}$ is the percentage of flats in the city which was taken as $20 \%$. At the same time, $F_{a}$ is the average roof area for the flats in the city, which was taken as $18.75 \mathrm{~m}^{2}$.

$$
\mathrm{RA}=\left(H_{p} \times H_{a}+F_{p} \times F_{a}\right) / 100
$$

The average RA for the city was calculated as $90.15 \mathrm{~m}^{2}$ using these values. For the sake of convenience, the value is rounded off to $90 \mathrm{~m}^{2}$. This value is used to calculate all three sites since there is not much change in the building dynamics across all sites.

\subsection{Rainwater Harvesting Potential}

The potential of the rainwater volume that can be stored monthly is calculated using Equation (2), where $C$ is the runoff coefficient, $A$ is the roof area calculated in metres square $\left(\mathrm{m}^{2}\right)$, and $i$ is the average monthly rainfall in millimeters $(\mathrm{mm})$.

$$
\text { Runoff }=C i A
$$

As mentioned before, a single average value of the roof area is used for all three sites. The average monthly rainfall for all three sites was used as a dataset in this equation, while the runoff coefficient was taken from the published literature. The coefficient of the runoff for multiple rooftops can be seen in Table 4 [49]. Since most of the rooftops in Islamabad are properly cemented, a 0.8 value was used in this study for all of the sites. California State Water Resources Control explained that the runoff coefficient is a dimensionless coefficient that relates the amount of runoff to the amount of precipitation received. Therefore, for tiled roofs, it ranges between $0.75-0.95$, and for concrete, it ranges between $0.8-0.95$. This research used a conservative figure to keep the values realistic.

Table 4. Coefficient of runoff for multiple rooftops [49].

\begin{tabular}{ccc}
\hline Surface & Type & Coefficient \\
\hline \multirow{3}{*}{ Roof } & Pitch roof tiles & $0.75-0.90$ \\
& Flat roof with a smooth surface & 0.5 \\
& Flat roof with gravel layer or thin turf $(<150 \mathrm{~mm})$ & $0.4-0.5$ \\
\hline
\end{tabular}

\subsection{Storage Tank Capacity}

To calculate potential harvesting, a roof area (RA) of $90 \mathrm{~m}^{2}$, a coefficient of 0.8 , and a monthly average rainfall for the last five years were used to find the monthly $\mathrm{RwH}$ potential in liters. From these monthly volumes, the cumulative volumes were obtained and plotted. Then, a constant demand line was drawn on a similar graph by considering constant withdrawal for the entire year. The greater difference between the demand line and the average rainfall provides the storage capacity of a tank that is meant to hold all of the rainwater. This difference helped us to understand when the rainwater availability was higher than the demand and that water should be stored for the scarcity months.

\section{Results}

This study mainly focused on determining the $\mathrm{RwH}$ potential in Islamabad. At first, three different sites were studied by gathering their daily rainfall data and then calculating average monthly rainfall, as given in Table 5 . This shows that most of the rainfall occurs in July and August because of the monsoon season in the region. On average, Site 1 receives $1435 \mathrm{~mm}$ of rainfall; Site 2 receives $1212 \mathrm{~mm}$, while Site 3 receives $1225 \mathrm{~mm}$ of rainfall 
annually, which helped us to understand the rainfall pattern in Islamabad and highlighted that Islamabad receives a fair amount of rainwater that can be stored and used for domestic utilities. It is worth mentioning that although all three sites are equally scattered, there is very little difference in the rainfall pattern because the season is a regional phenomenon. Therefore, any significant difference at the city level might not be witnessed.

Table 5. The monthly average rainfall of three sites.

\begin{tabular}{cccc}
\hline Month & $\begin{array}{c}\text { Average Rainfall } \\
(\mathbf{m m}) \text { Site } \mathbf{1}\end{array}$ & $\begin{array}{c}\text { Average Rainfall } \\
\mathbf{( m \mathbf { m } )} \text { Site } \mathbf{2}\end{array}$ & $\begin{array}{c}\text { Average Rainfall } \\
\mathbf{( m m )} \text { Site 3 }\end{array}$ \\
\hline January & 1.01 & 1.01 & 1.01 \\
February & 78.02 & 74.32 & 71.36 \\
March & 39.21 & 43.08 & 42.54 \\
April & 85.02 & 79.31 & 81.23 \\
May & 64.23 & 39.81 & 40.36 \\
June & 63.01 & 67.53 & 70.12 \\
July & 371.02 & 322.28 & 326.96 \\
August & 542.81 & 434.54 & 439.24 \\
September & 105.00 & 57.04 & 52.77 \\
October & 31.00 & 36.61 & 39.25 \\
November & 24.01 & 21.54 & 23.28 \\
December & 30.40 & 35.40 & 36.80 \\
\hline
\end{tabular}

After calculating the monthly average rainfall, building structures were drawn in InfraWorks ${ }^{\circledR}$ in all three sites. Existing buildings were considered for this study because it is more realistic to work on an existing building than it is to propose a new one. Since Islamabad is a well-designed and planned city, most of the houses in the city have similar infrastructure and features. A similar prototype is used for all of the sites, as most of the construction in this region is the same, as shown in Figure 6.

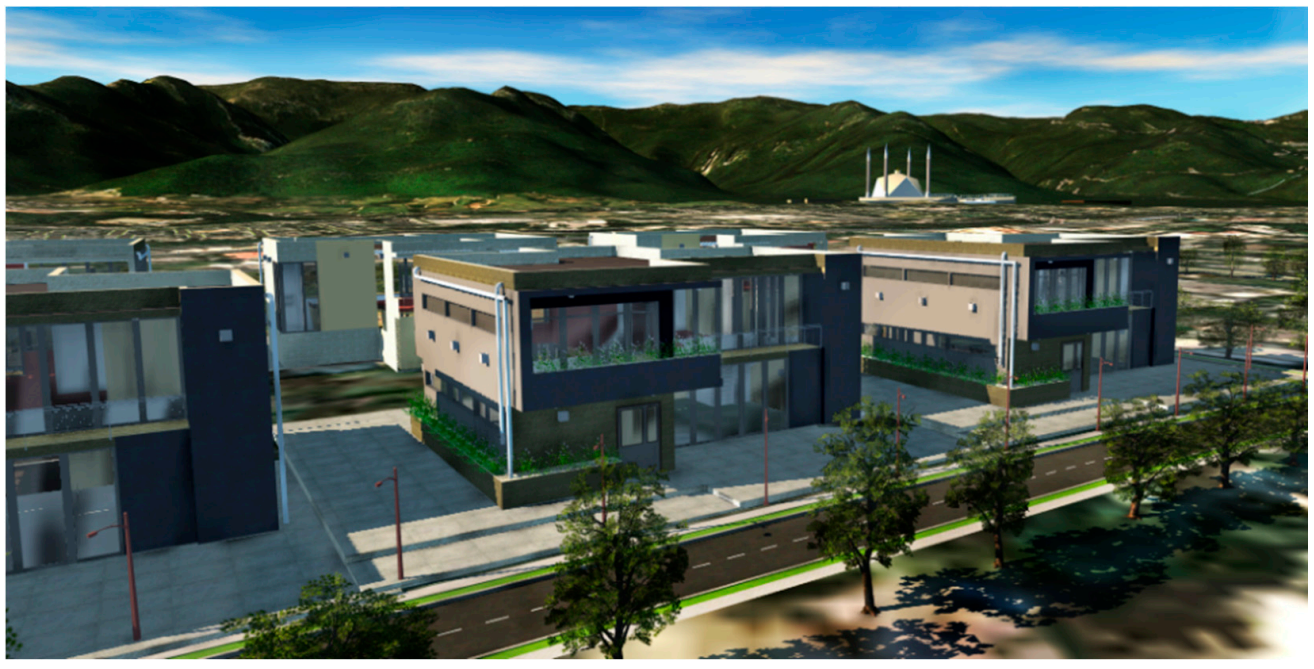

Figure 6. The proposed RwH structure of Site 1, 2 and 3 in InfraWorks.

Once the rooftops area, household number, and house surface area were statistically calculated, the RwH potential was calculated for all of the sites using Equation (2). After calculating the $\mathrm{RwH}$ potential for each month, the cumulative potential was also calculated for all of the sites and was plotted. Later, an assumption was made that the water demand would be constant throughout the entire year. Therefore, a cumulative line was used to determine the overall monthly water quantity that is required by keeping the demand in mind. The average water demand is added to each month, making it a cumulative value. This establishes a linear relationship between water demand and the months of the year. 
This idea was used to deduce the water demand for each month and to deduce the potential of rainwater harvesting. Decision makers can benefit from this concept by identifying the months in which water availability is at its maximum, and the water demands can be fulfilled using the conserved water sources.

Furthermore, in the months with maximum water demand and low supply, they can plan for the effective provision of water. Moreover, a water availability policy can be developed using the associated data. Hence, a cumulative demand line was drawn on cumulative potential graphs, which helped to identify each month's status as it related to potential storage, which helped to establish the demand profile and to show if there is more or less demand during particular parts of the year. Moreover, we also identified the month that receives the most excessive rainfall that could be stored and used in dry months. However, it is evident that the higher the rainfall, the larger the storage tank required to store the excess water.

\section{Rainwater Harvesting Potential at Investigated Site}

The results of Site 1,2, and 3 are given in Table 6, and the monthly distribution of RWH potential and its cumulative accumulation is shown in Figures 7-9, respectively. By comparing all of the sites, it can be concluded that Site 1 holds the maximum potential for $\mathrm{RwH}$, displaying the potential to store $56 \mathrm{~L}$ per day. Since the rooftop area and recharge coefficient are the same for all of the sites, there more rainfall in this area than there is in other sites. Hence, this area holds the maximum potential for water storage. However, this does not mean that the other sites do not have any potential; both Site 2 and Site 3 also receive a fair amount of rainfall. The rest of the area can also be used for $\mathrm{RwH}$. In short, the graph of the cumulative rainfall and the demand line show that August and September have more rainfall harvesting potential than the demand; hence, this extra water can be stored and used in dry months. Since all three sites have similar climatic conditions, not many variations can be seen in the sites. Therefore, all of the recommendations and strategies that can be applied to one site apply to others as well.

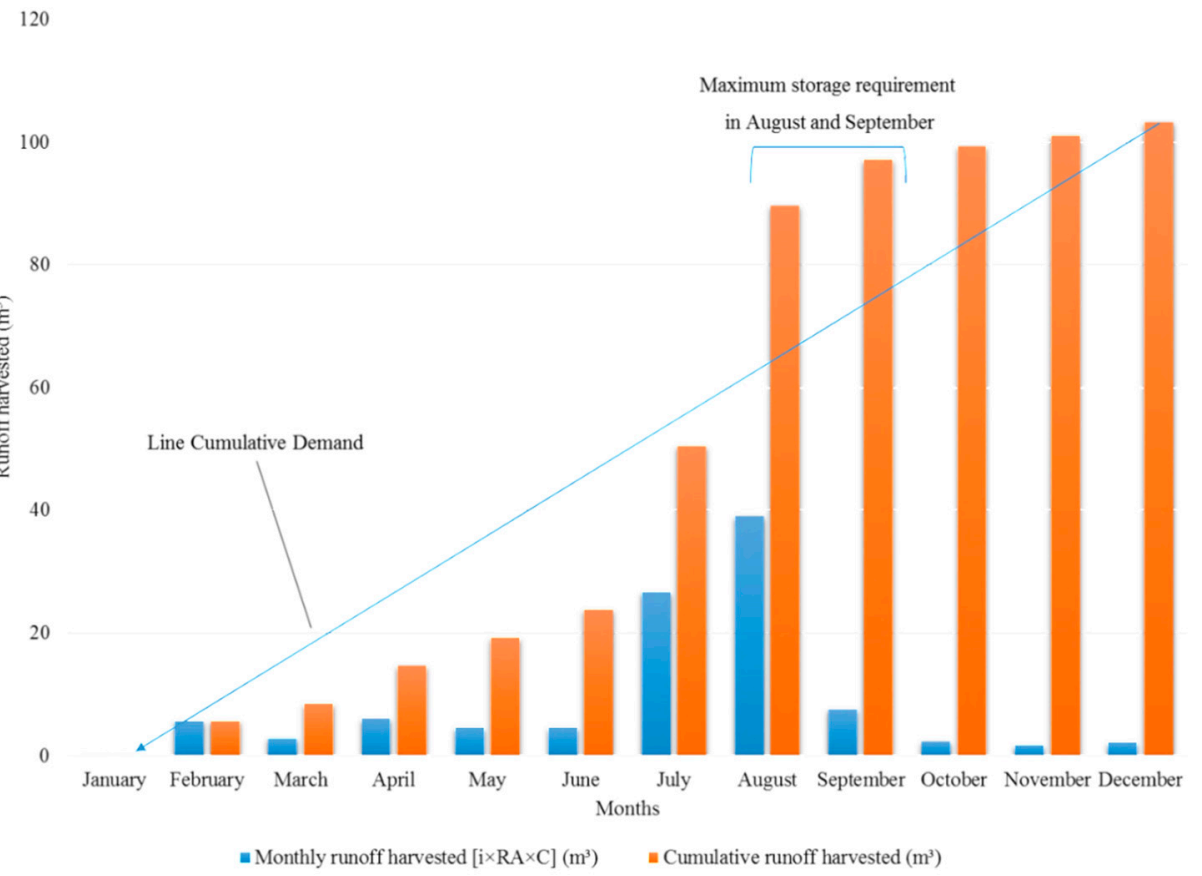

Figure 7. Rainwater harvesting and storage requirements of Site 1. 
Table 6. Rainwater harvesting potential on Sites 1,2 and 3.

\begin{tabular}{|c|c|c|c|c|c|c|c|c|c|c|c|}
\hline \multirow[b]{2}{*}{ Month } & \multicolumn{3}{|c|}{ Average Rainfall [i] (mm) } & \multirow[b]{2}{*}{$\begin{array}{l}\text { Roof Area } \\
\text { [RA] }\left(\mathrm{m}^{2}\right)\end{array}$} & \multirow{2}{*}{$\begin{array}{c}\text { Runoff } \\
\text { Coefficient } \\
{[C]}\end{array}$} & \multicolumn{2}{|c|}{ Site 1} & \multicolumn{2}{|c|}{ Site 2} & \multicolumn{2}{|c|}{ Site 3} \\
\hline & $\begin{array}{c}\text { Site } 1 \\
i_{1}\end{array}$ & $\begin{array}{c}\text { Site } 2 \\
i_{2}\end{array}$ & $\begin{array}{c}\text { Site } 3 \\
i_{3}\end{array}$ & & & $\begin{array}{c}\text { Monthly Runoff } \\
\text { Harvested }\left(i_{1} \times\right. \\
R A \times C)\left(\mathrm{m}^{3}\right)\end{array}$ & $\begin{array}{c}\text { Cumulative } \\
\text { Runoff Harvested } \\
\left(\mathrm{m}^{3}\right)\end{array}$ & $\begin{array}{l}\text { Monthly Runoff } \\
\text { Harvested }\left(i_{2} \times\right. \\
R A \times C)\left(\mathrm{m}^{3}\right)\end{array}$ & $\begin{array}{c}\text { Cumulative } \\
\text { Runoff Harvested } \\
\left(\mathrm{m}^{3}\right)\end{array}$ & $\begin{array}{l}\text { Monthly Runoff } \\
\text { Harvested }\left(i_{3} \times\right. \\
R A \times C)\left(\mathrm{m}^{3}\right)\end{array}$ & $\begin{array}{c}\text { Cumulative } \\
\text { Runoff Harvested } \\
\left(\mathrm{m}^{3}\right)\end{array}$ \\
\hline February & 78.02 & 74.32 & 71.36 & 90 & 0.8 & 5.61744 & 5.69016 & 5.35104 & 5.42376 & 5.13792 & 5.21064 \\
\hline March & 39.21 & 43.08 & 42.54 & 90 & 0.8 & 2.82312 & 8.51328 & 3.10176 & 8.52552 & 3.06288 & 8.27352 \\
\hline April & 85.02 & 79.31 & 81.23 & 90 & 0.8 & 6.12144 & 14.63472 & 5.71032 & 14.23584 & 5.84856 & 14.12208 \\
\hline May & 64.23 & 39.81 & 40.36 & 90 & 0.8 & 4.62456 & 19.25928 & 2.86632 & 17.10216 & 2.90592 & 17.028 \\
\hline June & 63.01 & 67.53 & 70.12 & 90 & 0.8 & 4.53672 & 23.796 & 4.86216 & 21.96432 & 5.04864 & 22.07664 \\
\hline July & 371.02 & 322.28 & 326.96 & 90 & 0.8 & 26.71344 & 50.50944 & 23.20416 & 45.16848 & 23.54112 & 45.61776 \\
\hline September & 105 & 57.04 & 52.77 & 90 & 0.8 & 7.56 & 97.15176 & 4.10688 & 80.56224 & 3.79944 & 81.04248 \\
\hline October & 31 & 36.61 & 39.25 & 90 & 0.8 & 2.232 & 99.38376 & 2.63592 & 83.19816 & 2.826 & 83.86848 \\
\hline November & 24.01 & 21.54 & 23.28 & 90 & 0.8 & 1.72872 & 101.11248 & 1.55088 & 84.74904 & 1.67616 & 85.54464 \\
\hline December & 30.4 & 35.4 & 36.8 & 90 & 0.8 & 2.1888 & 103.30128 & 2.5488 & 87.29784 & 2.6496 & 88.19424 \\
\hline
\end{tabular}




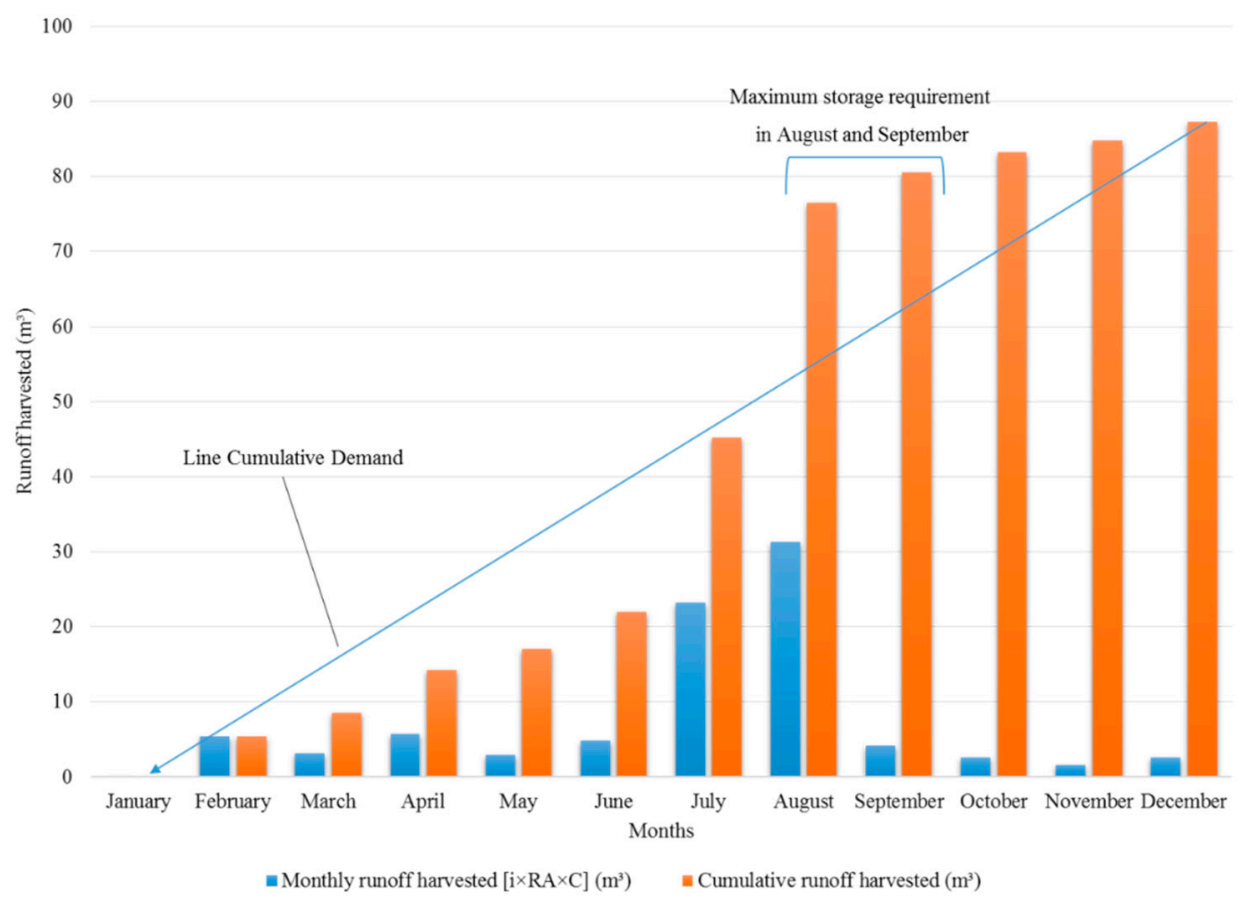

Figure 8. Rainwater harvesting and storage requirements of Site 2.

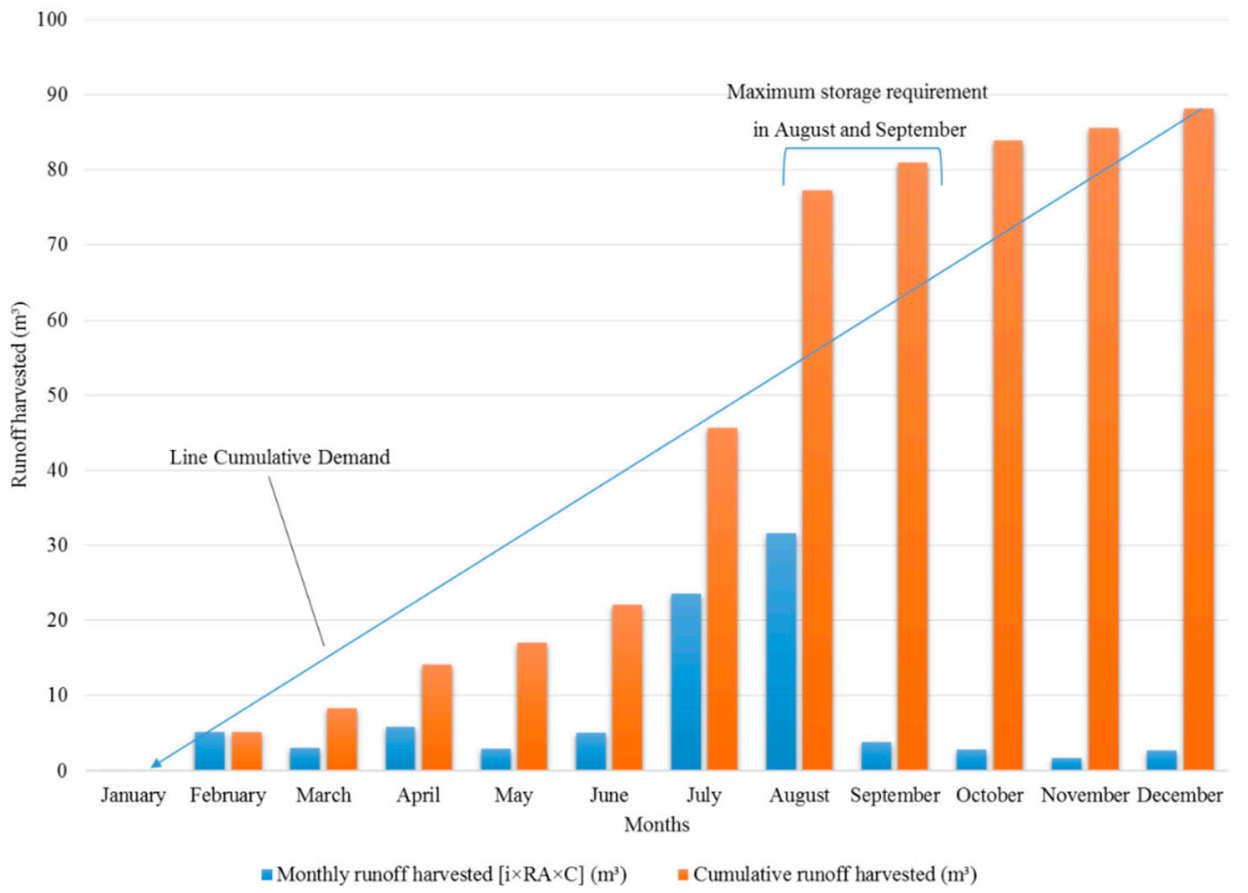

Figure 9. Rainwater harvesting and storage requirements of Site 3.

\section{RwH Technique Adoption and Discussion}

With increased water demand due to population growth, water usage and demand has increased, leading to the depletion of the groundwater aquifers. Water management is essential for water scarcity counting and requires proper governance and appropriate engineering solutions. Proper governance includes democratic legitimacy regarding this matter. Sophisticated frameworks of building structures and strategies such as green infrastructures should be adopted and implemented to achieve the holistic goals of smart and sustainable cities. Furthermore, stakeholders should be persuaded to collaborate on these developments through incentives from the government and regulatory bodies. Some 
measures in this context include subsidized developments that consider green strategies. Furthermore, proper sustainable drainage systems (SuDs) should be implemented to maximize the $\mathrm{RwH}$ potential globally. Once such strategies are implemented, $\mathrm{RwH}$ engineering solutions can be implemented, including small dams, pit holes, porous roads, and building structures with RwH and green infrastructures to move towards smart and sustainable cities and eventually to a smart planet, as per the United Nations' sustainable development goals (SDGs).

Governing principles and engineering solutions are difficult to implement and adopt. They require active collaboration between all stakeholders. Conventional construction and projects have many loopholes in the information sharing department, creating an environment of mistrust, ultimately leading to failures and ineffectiveness, both of which are evident in developing countries like Pakistan. BIM allows all stakeholders, including designers, owners, building specialists, and contractors, to collaborate closely [56].

Moreover, sustainability in $\mathrm{RwH}$ can only be achieved through a proper process such as BIM. Researchers have studied BIM technology for increasing water efficiency since it improves working efficiency, examines sustainability performance, and increases collaboration between multiple working groups [12]. It has been established that BIM increases time efficiency and enhances the coordination of construction projects [57]. BIM combines visibility, harmonization, modeling, and optimization, which are the key ingredients for enhancing model efficiency [58]. These findings are complemented by the outcomes of this research, where the benefits of BIM are acknowledged.

The current research investigates the $\mathrm{RwH}$ potential in Islamabad, the capital of Pakistan and detailed methodology flow chart is given in Figure 10. $\mathrm{RwH}$ is an excellent source of water storage in areas that have higher water stress and demand. It can be applied anywhere in the world for $\mathrm{RwH}$ modeling and potential identification. This study presents BIM as an effective method to identify $\mathrm{RwH}$ potential accurately without any complex functions. The associated models were developed based on local knowledge. The sites were visited on ground, and the common house structure $\left(108 \mathrm{~m}^{2}\right)$ was replicated using these tools. The rooftop slope can vary in different conditions. For estimating the rooftop area, satellite data can also be used, which is more accurate. Furthermore, if the rainwater harvesting techniques are considered for the whole city, then the satellite data are definitely recommended for appropriate, reliable and accurate results. Satellite data cover a large area, which is why it is recommended when the whole city is considered. However, due to the same nature and construction style at all of the sites considered here, a generic model was prepared after the survey of the specified area. Since the model was only developed and utilized to estimate the $\mathrm{RwH}$ potential of the structures, the evaporation factor was not induced in it. However, this should be included in future studies, which should define an evaporation constant while determining the $\mathrm{RwH}$ potential. As in most semi-arid regions, some fractions of the precipitation value fall into the evaporation counter, so it must be included and catered for in future research. According to building codes, for every 12 inches, there should be a step down of $\frac{1}{4}$ inch, approximately $1.19^{\circ}$. However, in this study, to make the rainwater flow off the roof quickly, we used $5^{\circ}$ slopes. The amendments in the bylaws regarding these techniques have been discussed with the local development authority (CDA). The results can be even more supportive on a large scale and for buildings with larger areas. Larger buildings will have a larger roof area, contributing to more rainwater being collected and harvested. 


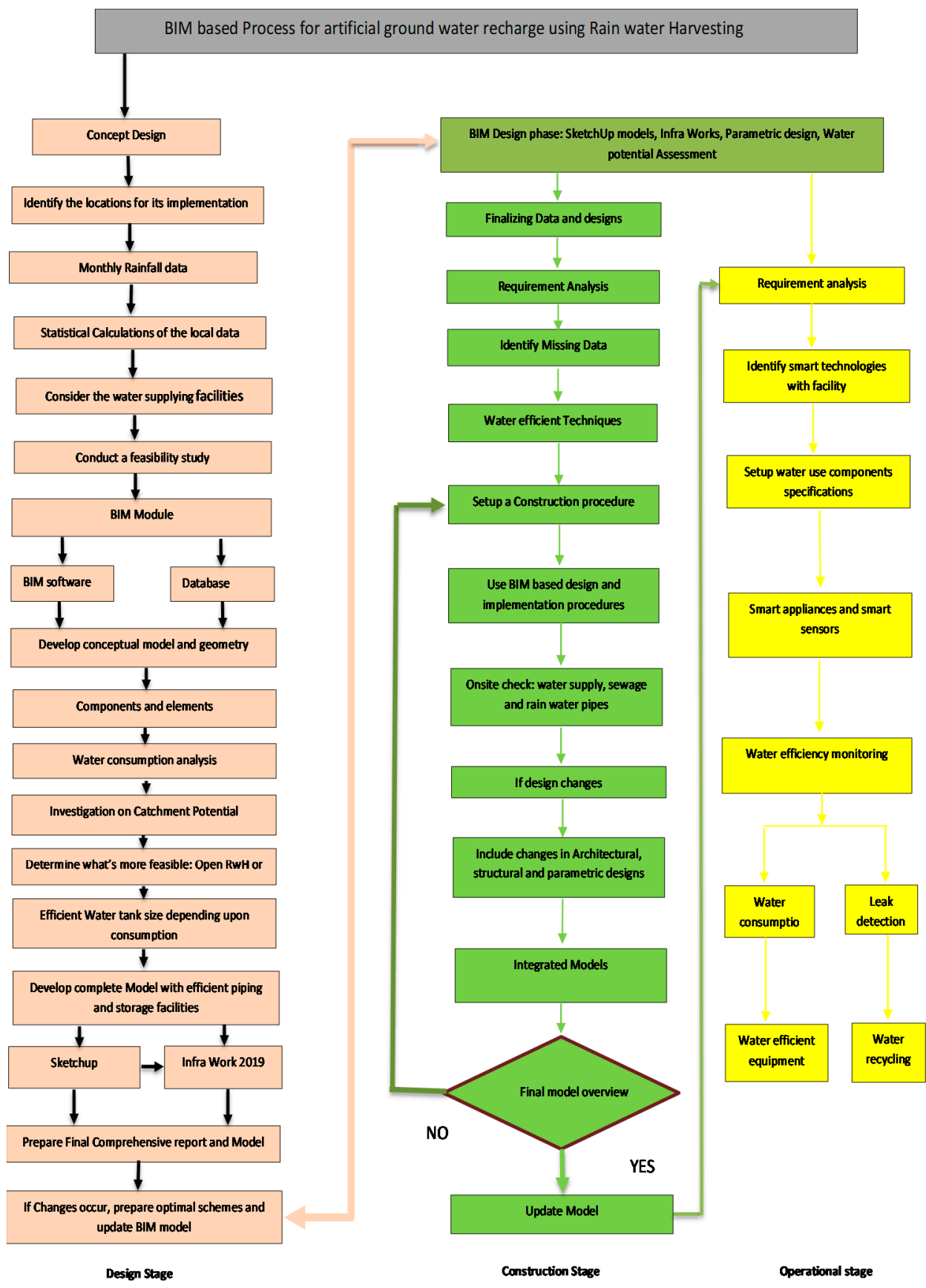

Figure 10. Stepwise automation process of RWH in BIM.

Moreover, water from multiple structures can be saved or allowed to move under gravitational flow. After natural purification, it will eventually be a source to recharge the groundwater table through soil layers. A study by Amos and Rahman [59] that was based on the economic analysis of RwH showed that more benefits can be achieved from such $\mathrm{RwH}$, which ultimately reduces the cost of water from the municipal supply. This is evident in countries such as Australia, where the benefit-cost ratio (BCR) is just over one, and for that reason, subsidiaries and the hedonic price were increased, which is ultimately advantageous for the user. However, the tank size, maintenance cost, and other factors are still in the research loop, and the considerations may not be exhaustive. A study by Stec [60] showed the cost and benefit analysis of RwH based on Equation (3). In Equation (3), LCC 
is the life cycle cost, INV is the investment of the project, OMC is the operating cost, and $\mathrm{DMC}$ is the cost of liquidation and economic use.

$$
\mathrm{LCC}=\mathrm{INV}+\mathrm{OMC}+\mathrm{DMC}
$$

Islamabad is prone to rainfall and has massive $\mathrm{RwH}$ potential. Water that can be saved using RwH structures can be utilized for bathing, washing, and gardening purposes. The following purposes save a great deal of water and are indeed very beneficial for the city. Since it is not being used for drinking purposes, there is no need to conduct a water quality check. The study showed that if the rainwater is utilized for domestic purposes, including bathing and gardening, then it can be a viable solution to solving household water demands and concerns. However, in the case of drinking, turbidity, acidity, biochemical oxygen demand, and a few other chemical and physical properties should be checked. The study by Rodríguez-Sinobas, Zubelzu [11] showed that a tank size of $7 \mathrm{~m}^{3}$ is beneficial for a household with more than two family members in Prague. Moreover, for low life cycle costs, OMC and INV should be less to adopt them easily. Accordingly, it will be beneficial when more people adopt this water saving methodology, and the long-term benefits of keeping water resources intact can be achieved.

Furthermore, this study also showed that water purification could be uneconomical when used for domestic purposes. In this way, time and financial resources can also be saved. Though this study concluded that BIM is a good technique to model the $\mathrm{RwH}$ potential, some contributing factors such as cost, legal requirements, etc., also need to be addressed for more reliable results and to propose holistic implementable solutions. Islamabad, which is located in a semi-arid climate, receives moderate rainfall over the entire year, except for during the monsoon season, when it rains excessively. Due to an increase in the population, water demand has increased drastically in this city.

Further, with continuous water pumping from groundwater and low water recharge, groundwater is depleting rapidly in this area. As such to overcome this problem, unconventional ways of storing water are mandatory for the study area. Thus, the $\mathrm{RwH}$ for household usage is an important method that was explored in this study. The process was visualized and complimented using BIM [61-63].

BIM provided a building modeling for all three sites. In the BIM environment, houses were modeled for all three sites, and calculations were performed. A simple methodology was followed in this research, where the water requirements per person per day were calculated, and the potential available water was calculated from simple statistical relationships. Afterward, the cumulative $\mathrm{RwH}$ was calculated and drawn against the demand line to identify the demand and availability of the water over the entire year. The results revealed that all three study sites have strong potential for rainwater storage. In terms of the monthly potential for $\mathrm{RwH}$, it was found that August and September provide enough water for storage that can be used during the dry winters (October to December), when the area receives lesser rainfall [64]. On the other hand, if the three sites are compared, then Site 1 has the maximum potential for rainwater storage, as it receives maximum rainfall. However, the other two sites also receive a fair amount of rainfall for water storage, which is enough to deal with the water requirements of local households.

The results confirm that the methodology adopted in the current study gives reliable results for the study area. However, it is important to mention that small storage units can be expensive, need larger financial expenditure, and provide relatively lower potential outcomes than larger structures [65]. This is why larger rainwater storage tanks or areas are recommended to achieve the maximum output from the harvested rainwater. According to the current CDA building code, the rainwater drainage of houses must be linked with the main CDA drainage system, the water in which will ultimately become waste. Furthermore, there is no reservoir in the buildings to conserve the harvested rainwater. According to a recent study, $\mathrm{RwH}$ was implemented in Faisal Mosque Islamabad, and it was determined that after three days of rain, the nearing groundwater level raised up to $4250 \mathrm{~mm}$. The technique included rooftop harvesting, directing the water into the ground by pit holes, 
and allowing it to flow using the action of gravity. A new CDA building code amendment was introduced to save water, which included conditions that roof $\mathrm{RwH}$ must be adopted in houses with an area of more than $38 \mathrm{~m}^{2}$. Thus, the topic under investigation is critical to the local authorities and is welcomed by them. The same approach can be adopted and investigated for other countries.

$\mathrm{RwH}$ is also common in agriculture practices, including small dams and pit holes, as large amounts of water are required for crops. Asadi and Bannayan [66] showed that low crop yields are obtained with low precipitation. To counter this water issue, $\mathrm{RwH}$ is promoted and contributes to domestic and agricultural purposes. Moreover, RwH shows great potential in semi-arid regions and can help sustain the agriculture sector. In Ethiopia, another study by Tolossa et al. [60] showed a significant impact of the RwH techniques and strategies that helped improve soil moisture, low runoff, increased groundwater recharge, and crop yield.

Openly harvested rainwater can be used for bathing, washing, and other domestic purposes. If any design plan changes, then the structure can be improved or amended using the same tools. The second stage is the construction stage, which includes the on-ground development of the structure. Finalized data and design need to be handed over to the implementers and constructors. A complete requirement sheet that shows the demand of all of the materials involved in the process, i.e., from excavation to the finishing stage of the buildings, can be created. More advanced and efficient techniques can be used to increase the efficiency of this structure. A detailed construction procedure can be set up using BIM processes, on-site sewerage, and rainwater structures linked with the built-up area. If some changes need to be induced, then they must be included in the architectural, structural, and parametric design to smoothen the project and to avoid confusion between different stakeholders. After this, the model can be updated and moved into the next stage. The third stage is related to the maintenance of the facility. Again, a requirement list can be formed, showing all of the equipment and material to be used for maintenance. Smart technologies and smart sensors can be utilized to check the facility and the associated water flow. The sensors can help in determining the quantity of water utilized and detecting any potential leakages. Furthermore, recycling rainwater can also be achieved using smart technologies for filtration. Hence, it can be said that this process is quite easy to adopt in all kinds of residential buildings.

\section{Conclusions}

This study examined the potential for $\mathrm{RwH}$ in oCfa-type climate cities and was carried out in the example city of Islamabad, Pakistan. Through BIM, houses were designed with local knowledge and observations. Later, the rooftop area was estimated, and the rainwater storage potential was empirically derived. The yearly accumulated rainfall of the three sites in the study area was used for pertinent calculations. It was concluded that the study area possesses a high potential for $\mathrm{RwH}$. Site 1 is the potential site for maximum $\mathrm{RwH}$, where an average of $56 \mathrm{~L}$ per day can be stored.

Further, considering the constant demand and cumulative rainwater storage, it was deduced that August and September have more water availability than demand. Hence, excessive water can be stored for use during the dry months in these rainier months. Based on the RwH potential analysis, it can be concluded that Islamabad has very good potential for $\mathrm{RwH}$. A fair amount of water can be stored for domestic and commercial usage. Thus, this research provides a baseline for the application of BIM in $\mathrm{RwH}$ potential assessment and management.

Theoretically, this research provides a baseline methodology for identifying the potential of $\mathrm{RwH}$ worldwide and in other regions of Pakistan. By following this methodology, RwH potential and household demand and supply state can be drawn for global cities in both developing and developed countries. In the past, rainwater was stored and utilized for agriculture and households. However, it was never considered a practice to utilize a small region or town's water supply potential. Therefore, BIM provides the theoretical baseline 
for identifying rainwater potential and its utility in different seasons. This methodology can be applied globally to address the water crisis issues and the associated town/city management issues. To estimate the roof areas, scholars may use satellite images for the large regions in their study, as this will yield more accurate results. Practically, this research proposes the amount of rainwater that is available to be harvested in Islamabad, which will help decision makers select appropriate sites for water storage and to formulate policies for the implementation of rainwater storage designs and water management. The local development authority has welcomed the findings, and changes to building bylaws are in progress to accommodate $\mathrm{RwH}$-associated changes in local buildings. Other countries can adopt the same approach to tap into the holistic benefits of BIM-based $\mathrm{RwH}$.

Author Contributions: Conceptualisation, A.M., B.A. and S.I.; methodology, A.M., B.A. and S.I.; software, A.M., B.A. and S.I.; validation, A.M., B.A., M.J.T., H.Z. and F.U.; formal analysis, A.M., B.A. and S.I.; investigation, A.M., B.A. and S.I.; resources, M.J.T., H.Z., F.U., M.A.M. and N.I.V.; data curation, A.M., B.A., M.J.T., H.Z. and F.U.; writing-original draft preparation, A.M., B.A. and S.I.; writing-review and editing, M.J.T., H.Z. and F.U.; visualization, A.M., B.A. and S.I.; supervision, A.M., M.J.T., H.Z. and F.U.; project administration, F.U., M.A.M. and N.I.V.; funding acquisition, M.A.M. and N.I.V. All authors have read and agreed to the published version of the manuscript.

Funding: The research is partially funded by the Ministry of Science and Higher Education of the Russian Federation as part of the World-class Research Center program: Advanced Digital Technologies (contract No. 075-15-2020-934 dated 17 November 2020).

Institutional Review Board Statement: Not applicable.

Informed Consent Statement: Not applicable.

Data Availability Statement: Not applicable.

Acknowledgments: The authors would like to thank Comsats University, Riphah University, Deakin University, NUST, University of Southern Queensland, and Universiti Teknologi PETRONAS (UTP) for the support provided for this research.

Conflicts of Interest: The authors declare no conflict of interest.

\section{References}

1. Raghav, S.; Painuli, R.; Kumar, D. Threats to water: Issues and challenges related to ground water and drinking water. In $A$ New Generation Material Graphene: Applications in Water Technology; Naushad, M., Ed.; Springer International Publishing: New York City, NY, USA, 2019; pp. 1-19.

2. Samir, K.; Lutz, W. The human core of the shared socioeconomic pathways: Population scenarios by age, sex and level of education for all countries to 2100. Glob. Environ. Chang. 2017, 42, 181-192.

3. Hao, T.; Du, P.; Gao, Y. Water environment security indicator system for urban water management. Front. Environ. Sci. Eng. 2012, 6, 678-691. [CrossRef]

4. Herrmann, C.; Schmidt, C.; Kurle, D.; Blume, S.; Thiede, S. Sustainability in manufacturing and factories of the future. Int. J. Precis. Eng. Manuf. Technol. 2014, 1, 283-292. [CrossRef]

5. Pérez, A.; Hurtado-Patiño, J.; Herrera, H.; Carvajal, A.; Pérez, M.; Gonzalez-Rojas, E.; Pérez-García, J. Assessing sub-regional water scarcity using the groundwater footprint. Ecol. Indic. 2019, 96, 32-39. [CrossRef]

6. Adnan, S.; Ullah, K.; Gao, S.; Khosa, A.H.; Wang, Z. Shifting of agro-climatic zones, their drought vulnerability, and precipitation and temperature trends in Pakistan. Int. J. Clim. 2017, 37, 529-543. [CrossRef]

7. Tiwari, K.; Goyal, R.; Sarkar, A. GIS-based methodology for identification of suitable locations for rainwater harvesting structures. Water Resour. Manag. 2018, 32, 1811-1825. [CrossRef]

8. Aslam, B.; Maqsoom, A.; Khalid, N.; Ullah, F.; Sepasgozar, S. Urban overheating assessment through prediction of surface temperatures: A case study of Karachi, Pakistan. ISPRS Int. J. Geo-Inf. 2021, 10, 539. [CrossRef]

9. Wang, R.; Zimmerman, J. Economic and environmental assessment of office building rainwater harvesting systems in various U.S. cities. Environ. Sci. Technol. 2015, 49, 1768-1778. [CrossRef]

10. Rice, J.; Martin, N. Smart infrastructure technologies: Crowdsourcing future development and benefits for Australian communities. Technol. Forecast. Soc. Chang. 2020, 153, 119256. [CrossRef]

11. Rodríguez-Sinobas, L.; Zubelzu, S.; Perales-Momparler, S.; Canogar, S. Techniques and criteria for sustainable urban stormwater management: The case study of Valdebebas (Madrid, Spain). J. Clean. Prod. 2018, 172, 402-416. [CrossRef]

12. Lupia, F.; Baiocchi, V.; Lelo, K.; Pulighe, G. Exploring rooftop rainwater harvesting potential for food production in urban areas. Agriculture 2017, 7, 46. [CrossRef] 
13. Ali, B.; Zahoor, H.; Nasir, A.R.; Maqsoom, A.; Khan, R.W.A.; Mazher, K.M. BIM-based claims management system: A centralized information repository for extension of time claims. Autom. Constr. 2020, 110, 102937. [CrossRef]

14. Ullah, F.; Qayyum, S.; Thaheem, M.J.; Al-Turjman, F.; Sepasgozar, S.M. Risk management in sustainable smart cities governance: A TOE framework. Technol. Forecast. Soc. Chang. 2021, 167, 120743. [CrossRef]

15. Ullah, F.; Sepasgozar, S.M.; Thaheem, M.J.; Al-Turjman, F. Barriers to the digitalisation and innovation of Australian Smart Real Estate: A managerial perspective on the technology non-adoption. Environ. Technol. Innov. 2021, 22, 101527. [CrossRef]

16. Ullah, F.; Sepasgozar, S.M.; Shirowzhan, S.; Davis, S. Modelling users' perception of the online real estate platforms in a digitally disruptive environment: An integrated KANO-SISQual approach. Telematics Informatics 2021, 63, 101660. [CrossRef]

17. Ullah, F.; Sepasgozar, S.M.; Thaheem, M.J.; Wang, C.C.; Imran, M. It's all about perceptions: A DEMATEL approach to exploring user perceptions of real estate online platforms. Ain Shams Eng. J. 2021. [CrossRef]

18. Ullah, F.; Thaheem, M.J.; Sepasgozar, S.M.E.; Forcada, N. System dynamics model to determine concession period of PPP Infrastructure Projects: Overarching effects of critical success factors. J. Leg. Aff. Disput. Resolut. Eng. Constr. 2018, 10, 04518022. [CrossRef]

19. Hamidavi, T.; Abrishami, S.; Hosseini, M. Towards intelligent structural design of buildings: A BIM-based solution. J. Build. Eng. 2020, 32, 101685. [CrossRef]

20. Maqsoom, A.; Khan, M.U.; Khan, S.; Naeemullah; Ullah, F. Factors influencing the construction time and cost overrun in projects: Empirical evidence from Pakistani construction industry. In Proceedings of the Proceedings of the 21st International Symposium on Advancement of Construction Management and Real Estate; Chau, K., Chan, I., Lu, W., Webster, C., Eds.; Springer: Singapore, Singapore, 2018; pp. 769-778.

21. Lotfi, N.; Behnam, B.; Peyman, F. A BIM-based framework for evacuation assessment of high-rise buildings under post-earthquake fires. J. Build. Eng. 2021, 43, 102559. [CrossRef]

22. Ali, Q.; Thaheem, M.J.; Ullah, F.; Sepasgozar, S.M.E. The performance gap in energy-efficient office buildings: how the occupants can help? Energies 2020, 13, 1480. [CrossRef]

23. Trindade, A.D.; Coelho, G.B.; Henriques, F.M. Influence of the climatic conditions on the hydrothermal performance of autoclaved aerated concrete masonry walls. J. Build. Eng. 2021, 33, 101578. [CrossRef]

24. Panteli, C.; Kylili, A.; Stasiuliene, L.; Seduikyte, L.; Fokaides, P.A. A framework for building overhang design using Building Information Modeling and Life Cycle Assessment. J. Build. Eng. 2018, 20, 248-255. [CrossRef]

25. Siddiqui, M.Z.; Pearce, A.R.; Ku, K.; Langar, S.; Ahn, Y.H.; Jacocks, K. Green BIM approaches to architectural design for increased sustainability. Available online: https://www.researchgate.net/publication/236878118_Green_BIM_Approaches_to_ Architectural_Design_for_Increased_Sustainability (accessed on 6 July 2021).

26. Badenkoa, V.; Bolshakov, N.; Tishchenkob, E.; Celanic, A.; Fedotova, A.; Yadykina, V. Integration of digital twin and BIM technologies within factories of the future. Mag. Civ. Engineering. 2021, 101, 10114.

27. Langar, S.; Pearce, A.R. Implementation trends for rainwater-harvesting technologies and strategies and their relationship with Building Information Modeling. J. Arch. Eng. 2017, 23, 04016016. [CrossRef]

28. Qureshi, A.S. Groundwater Governance in Pakistan: From Colossal Development to Neglected Management. Water 2020, 12, 3017. [CrossRef]

29. Arshad, A.; Zhang, Z.; Zhang, W.; Dilawar, A. Mapping favorable groundwater potential recharge zones using a GIS-based analytical hierarchical process and probability frequency ratio model: A case study from an agro-urban region of Pakistan. Geosci. Front. 2020, 11, 1805-1819. [CrossRef]

30. Raza, M.; Hussain, F.; Lee, J.-Y.; Shakoor, M.B.; Kwon, K.D. Groundwater status in Pakistan: A review of contamination, health risks, and potential needs. Crit. Rev. Environ. Sci. Technol. 2017, 47, 1713-1762. [CrossRef]

31. Yeh, H.-F.; Lin, H.-I.; Lee, C.-H.; Hsu, K.-C.; Wu, C.-S. Identifying seasonal groundwater recharge using environmental stable isotopes. Water 2014, 6, 2849-2861. [CrossRef]

32. Bhutta, M.N.; Alam, M.M. Prospectives and Limits of Groundwater Use in Pakistan. Available online: https:// publications.iwmi. org/pdf/H039312.pdf (accessed on 6 July 2021).

33. Farid, M.; Irshad, M.; Fawad, M.; Ali, Z.; Eneji, A.E.; Aurangzeb, N.; Mohammad, A.; Ali, B. Effect of cyclic phytoremediation with different wetland plants on municipal wastewater. Int. J. Phytoremediation 2013, 16, 572-581. [CrossRef]

34. Gallardo, A.H. Hydrogeological characterisation and groundwater exploration for the development of irrigated agriculture in the West Kimberley region, Western Australia. Groundw. Sustain. Dev. 2018, 8, 187-197. [CrossRef]

35. Mun, J.; Han, M. Design and operational parameters of a rooftop rainwater harvesting system: Definition, sensitivity and verification. J. Environ. Manag. 2012, 93, 147-153. [CrossRef] [PubMed]

36. Pacheco, P.R.D.C.; Gómez, Y.D.; de Oliveira, I.F.; Teixeira, L.C.G. A view of the legislative scenario for rainwater harvesting in Brazil. J. Clean. Prod. 2017, 141, 290-294. [CrossRef]

37. Azhar, S.; Nadeem, A.; Mok, J.Y.; Leung, B.H. Building Information Modeling (BIM): A new paradigm for visual interactive modeling and simulation for construction projects. In Proceedings of the First International Conference on Construction in Developing Countries (ICCIDC-I), Karachi, Pakistan, 4-5 August 2008.

38. Najjar, M.; Figueiredo, K.; Palumbo, M.; Haddad, A. Integration of BIM and LCA: Evaluating the environmental impacts of building materials at an early stage of designing a typical office building. J. Build. Eng. 2017, 14, 115-126. [CrossRef] 
39. Gourlis, G.; Kovacic, I. Building Information Modelling for analysis of energy efficient industrial buildings-A case study. Renew. Sustain. Energy Rev. 2017, 68, 953-963. [CrossRef]

40. Ku, K.; Taiebat, M. BIM Experiences and Expectations: The Constructors' Perspective. Int. J. Constr. Educ. Res. 2011, 7, 175-197. [CrossRef]

41. Azhar, S.; Brown, J.W.; Sattineni, A. A case study of building performance analyses using Building Information Modeling. In Proceedings of the 27th International Symposium on Automation and Robotics in Construction; International Association for Automation and Robotics in Construction (IAARC), Bratislava, Slovakia, 25-27 June 2010; pp. 213-222. [CrossRef]

42. Azhar, S.; Carlton, W.A.; Olsen, D.; Ahmad, I. Building information modeling for sustainable design and LEED ${ }^{\circledR}$ rating analysis. Autom. Constr. 2011, 20, 217-224. [CrossRef]

43. Eastman, C.M.; Jeong, Y.-S.; Sacks, R.; Kaner, I. Exchange model and exchange object concepts for implementation of national BIM standards. J. Comput. Civ. Eng. 2010, 24, 25-34. [CrossRef]

44. Kensek, K. BIM Guidelines Inform Facilities Management Databases: A Case Study over Time. Buildings 2015, 5, 899-916. [CrossRef]

45. Ahmad, Z.; Thaheem, M.J.; Maqsoom, A. Building information modeling as a risk transformer: An evolutionary insight into the project uncertainty. Autom. Constr. 2018, 92, 103-119. [CrossRef]

46. Qayyum, S.; Ullah, F.; Al-Turjman, F.; Mojtahedi, M. Managing smart cities through six sigma DMADICV method: A review-based conceptual framework. Sustain. Cities Soc. 2021, 71, 103022. [CrossRef]

47. Barlish, K.; Sullivan, K. How to measure the benefits of BIM-A case study approach. Autom. Constr. 2012, 24, 149-159. [CrossRef]

48. Tang, F.; Ma, T.; Guan, Y.; Zhang, Z. Parametric modeling and structure verification of asphalt pavement based on BIM-ABAQUS. Autom. Constr. 2020, 111, 103066. [CrossRef]

49. Leggett, D.; Brown, R.; Stanfield, G.; Brewer, D.; Holli, E. Rainwater and Greywater Recycling in Buildings: Decision Making for Water Conservation; CIRIA: London, UK, 2001.

50. Ayub, B.; Ullah, F.; Rasheed, F.; Sepasgozar, S. Risks in EPC hydropower projects: A case of Pakistan. In Proceedings of the 8th International Civil Engineering Congress (ICEC) Ensuring Technological Advancement through Innovation Based Knowledge Corridor, Karachi, Pakistan, 23-24 December 2016.

51. Ghisi, E. Potential for potable water savings by using rainwater in the residential sector of Brazil. Build. Environ. 2006, 41, 1544-1550. [CrossRef]

52. Yaqub, M. Open Source Architecture: Redefining Residential Architecture in Islamabad. Ph.D. Thesis, Roger Williams University, Bristol, RI, USA, 2017.

53. Bulbul, G.; Shahid, I.; Chishtie, F.; Shahid, M.Z.; Hundal, R.A.; Zahra, F.; Shahzad, M.I. PM10 sampling and AOD trends during 2016 winter fog season in the Islamabad Region. Aerosol. Air Qual. Res. 2018, 18, 188-199. [CrossRef]

54. Sheikh, M.M.; Manzoor, N.; Adnan, M.; Ashraf, J.; Khan, A. Climate profile and past climate changes in Pakistan; Global Change Impact Studies Center (GCISC)-RR-01; Global Change Impact Studies Centre: Islamabad, Pakistan, 2009.

55. Partzsch, L. Smart regulation for water innovation-the case of decentralized rainwater technology. J. Clean. Prod. 2009, 17, 985-991. [CrossRef]

56. Langar, S. The role of building information modeling (BIM) in the implementation of rainwater harvesting technologies and strategies (RwHTS). Ph.D. Thesis, Virginia Polytechnic Institute and State University, Blacksburg, VA, USA, June 2013.

57. Rehman, M.S.U.; Thaheem, M.J.; Nasir, A.R.; Khan, K.I.A. Project schedule risk management through building information modelling. Int. J. Constr. Manag. 2020, 1-11. [CrossRef]

58. Lee, C.-Y.; Chong, H.-Y.; Wang, X. Streamlining digital modeling and Building Information Modelling (BIM) uses for the oil and gas projects. Arch. Comput. Methods Eng. 2018, 25, 349-396. [CrossRef]

59. Amos, C.; Rahman, A.; Gathenya, J.M. Economic analysis of rainwater harvesting systems comparing developing and developed countries: A case study of Australia and Kenya. J. Clean. Prod. 2018, 172, 196-207. [CrossRef]

60. Stec, A. Sustainable Water Management in Buildings; Springer: Berlin Germany, 2020; p. 90.

61. Ullah, F.; Sepasgozar, S.M.E.; Wang, C. A systematic review of smart real estate technology: Drivers of, and barriers to, the use of digital disruptive technologies and online platforms. Sustainability 2018, 10, 3142. [CrossRef]

62. Ullah, F. A beginner's guide to developing review-based conceptual frameworks in the built environment. Architecture 2021, 1, 5-24. [CrossRef]

63. Malik, Q.; Nasir, A.R.; Muhammad, R.; Thaheem, M.J.; Ullah, F.; Khan, K.I.A.; Hassan, M.U. BIMp-Chart-A Global Decision Support System for Measuring BIM Implementation Level in Construction Organizations. Sustainability 2021, 13, 9270. [CrossRef]

64. Dahutia, P.; Pathak, B.; Bhuyan, P.K. Aerosols characteristics, trends and their climatic implications over Northeast India and adjoining South Asia. Int. J. Clim. 2018, 38, 1234-1256. [CrossRef]

65. Lasage, R.; Verburg, P.H. Evaluation of small scale water harvesting techniques for semi-arid environments. J. Arid. Environ. 2015, 118, 48-57. [CrossRef]

66. Asadi, S.; Bannayan, M.; Monti, A. The association of crop production and precipitation; a comparison of two methodologies. Arid. Land Res. Manag. 2018, 33, 155-176. [CrossRef] 